\title{
APPLICATION OF EXPERT SYSTEMS FOR SELECTION OF INSTALLATION PIPES
}

\author{
Roberto Lujić, Ivan Samardžić, Vjekoslav Galzina
}

Preliminary notes

The enterprises want to minimise the overall production costs, to maintain the quality and to increase the competitiveness on the market. It is possible to increase the number of customers, efficiency and effectiveness through the product quality. Therefore, every enterprise needs to have a good organisational structure, good experts and the knowledge how to do qualitative work. The paper shows the application of expert system to the problem of selection of installation pipes according to the given attributes. The input attributes are: mechanical load, material, colour, flame resistance, length, packaging, temperature range and outer diameter. The output parameter is the type of installation pipe. The expert system can give a second opinion, explicitly and in detail. They have the intelligent database and the possibility to adopt new knowledge, but also have a disadvantage that they use only the stored data to create solutions. Therefore, it is necessary to change the data according to a situation in the given environment. Despite the disadvantages of expert systems, their application is becoming increasingly important for the progress of enterprises.

Keywords: artificial intelligence; expert systems; installation pipes

Primjena ekspertnih sustava kod izbora instalacijskih cijevi

Prethodno priopćenje

Svako poduzeće želi smanjiti ukupne troškove proizvodnje, zadržati kvalitetu i poboljšati konkurentnost. Kroz kvalitetu proizvoda cilj je povećati broj kupaca, ali u isto vrijeme i učinkovitost i efikasnost. Stoga, svako poduzeće mora imati dobru organizacijsku strukturu, dobre stručnjake i znanja kako obaviti posao kvalitetno. Rad pokazuje primjenu ekspertnog sustava na problemu izbora instalacijskih cijevi prema zadanim atributima. Ulazni atributi su: mehanička opterećenja, materijal, boja, otpornost na vatru, dužina, pakiranje, raspon temperature i vanjski promjer; a izlazni parametar je tip cijevi za ugradnju. Ekspertni sustav može dati drugo mišljenje, jasna i detaljna objašnjenja postupka zaključivanja. Imaju inteligentnu bazu podataka i mogućnost da usvajaju nova znanja, ali i nedostatak da koriste samo pohranjene podatke te preko njih stvaraju rješenja. Stoga je nužnost vršiti promjene u bazi u skladu sa situacijom iz okruženja. Unatoč nedostacima ekspertnih sustava,oni postaju sve važniji za napredovanje poduzeća.

Ključne riječi: cijevi; ekspertni sustavi; umjetna inteligencija

\section{Introduction}

With the transition from the information society to knowledge society, knowledge becomes the advantage for the individual, enterprise or state, because the competition is greater every day [1].

Over the years, the computer science has increasingly developed and progressed. The implementation and application of information in the computer system become more and more important.

The goal of any enterprise should be the organisational structure which will enable stable business transactions, easy and fast development, optimal use of material and human resources, and quick response to the changes in the environment. Each enterprise should strive for the leadership position, which will allow the initiation, creation and dictation of changes that will set the competition in an inauspicious position. According to the above mentioned, the following requirements are set by the customers and market: quality, price and delivery dates. Based on these demands and their realisation according to the customer requirements, the continuation of production will be possible [2].

The paper describes the artificial intelligence as a branch of computer science that deals with the designing of systems with some kind of intelligence, with the possibility to learn and to adopt new knowledge, to solve problems and to make decisions for which the human type of intelligence is necessary.

Because of the possibility of human mistakes and their fluctuation, the enterprises have the need to implement the expert systems and artificial intelligence tools [1].
The expert systems contain the specific knowledge from one or more fields of science. Because of the high degree of solving problems, the expert systems are often used in the enterprises. They can find an approximate solution even if the problem data are not complete, and at the same time, they can explain how and why the specific solutions have been chosen and which steps have been taken during the problem solving. The implementation of new knowledge and flexible strategy of problem solving are the possibilities of expert systems, as well.

The paper shows the possibility of application of expert system for the selection of installation pipes. The suggested model takes into consideration different attributes (e.g. mechanical load, material, colour, flame resistance, length) which increases the reliability and model complexity. All these aspects of technical and technological properties given through the attributes are the subject of scientific investigations, especially in their exploitation with different approaches: from the recent development of selection of infrastructure with the condition monitoring [3] to the prediction of material properties by means of different probabilistic models [4] and expert systems in the combination with the monitoring data [5], or complete selection models in the initial design stages [6]. The methodology used in the selection can be of different complexity, e.g. the decision making methodology with a compromise ranking method $[6,7]$. Nevertheless, to our best knowledge, this presented usage is not explicitly investigated, and in practice, the users mostly have faith in the human expertise and various product catalogues.

Today, the experts in production have to make a reliable decision as soon as possible, and to know everything about the production process at any moment. 
The application of artificial intelligence and expert systems in the single and small scale enterprises leads to the improvement of organisational structure, organisation of production preparation and manufacturing, decrease of preparation times, increase of productivity and decrease of production costs.

\section{Artificial intelligence and expert systems}

The notation of artificial intelligence is given to any inanimate system, which shows the capability to cope with the new situations. The artificial intelligence produces intelligent machines which act in the same way as people do.

There are many different definitions of artificial intelligence. According to [1] Marvin Minsky, the artificial intelligence is the science of making machines do things that would require intelligence if done by man.

The original idea for the artificial intelligence has been generated from the set of trials to make a biophysiological model of human brain with the goal to understand and to explain the brain functions and functionality. It means that the model needs to have the information processing ability (to adopt, to process, to generate, to store and to transfer) that is analogue to the human brain activities [8].

There are two approaches in the artificial intelligence modelling [8]:

1. The first has the goal to make the models which can imitate the human brain activities with high accuracy that finally has to lead to an artificial intelligence system.

2. The second approach implies the development of artificial neural networks with the huge computer capabilities oriented at solving the specific practical problems (neurocomputer).

The expert systems, as one of the most important areas of artificial intelligence, are defined in many different ways, but according to the most simplified definition, they are the systems that simulate the knowledge of experts. The expert system is a computer programme that emulates the conclusion process of one or more experts [9].

They contain the knowledge base and mechanisms for the problem solving which requires the human intelligence. The communication between the system and human beings is through the set of dialogues that have been implemented in the structure and according to that they try to understand the end-user problem. The system's way of thinking has been structured in such a way that it is understandable to the end-user, and at the same time, to be adaptable to describe the end-user's problem in a way that could be solved [9].

The expert systems are the highly developed form of information storage and transfer. Unlike the traditional programmes that have the operating system and applications programmes, the expert systems have the knowledge base, the conclusion mechanism and the user interface.

The traditional programmes have the algorithm structures where the end solutions are anticipated, while the expert systems can also process the undetermined situations.

The expert system strategy depends on the control structures that are incorporated in the conclusion mechanism that combines the fact and rules from the knowledge base in order to solve the end-user problem. It is necessary to choose the shortest scanning time of all potential solutions.

Two basic scanning approaches are [9]:

- to find a successful way of scanning the range of possible solutions and

- to find the way to ignore the unnecessary scans.

Today, the expert systems cover all areas of human lives. Due to the economic reasons, the expert systems are introduced in all engineering fields, especially where some facts exist that can be easily formalised as laws.

\section{Proposed model for the selection of installation pipes}

Due to their excellent chemical properties, plastic materials find their usage in electrical engineering, electronics and architecture. Compared with the traditional (steel) pipes, the plastic pipes have the following advantages in different application areas: no corrosion, no fluctuating current, ideally smooth surface, stability and persistence, simplicity and speed of pipe laying, frost resistance and low surface condensation, resistance to impacts, pressure and shocking, easy identification and packaging.

The basic material for the production of pipes is the plastic material (polyvinyl chloride) which can soften with the increase of temperature, and indurate at the lower temperature. It consists of a mixture of polyvinyl chloride and the additives that are necessary for better machinability. The material for pipe production has been prepared for the polymerisation; the process of mixing of polyvinyl chloride with the stabilizer based on lead, barium, tin or calcium soaps. The production process consists of the extrusion of plastic pipes and injection moulding. The pipes have been produced by the extrusion process where the synthetic thermal material has been molten, and over the helicoid bolt, injected in the machine. Afterwards, the pipes have been calibrated, cooled and cut to a specific length. The produced pipes have been wound onto the reels and sent to the warehouse.

The investigation has to show the possibility of applying the expert systems for the selection of type of installation pipes according to the defined attributes.

According to the performed analysis of manifestations in the process of selection of installation pipes, the following attributes have been chosen. Some of them are simple, and others are complex, and depend on some other values.

The following attributes according to the internal catalogue $[10,11]$ are taken into consideration (Tab. 1).

After the goal is set, the expert system has to give the answer to the following question: Which installation pipe will be chosen according to the suggested attributes?

The solution of model will be a decision tree where the expert system alone choses the basic attribute. The decision tree consists of nodes, leaves and null-leaves. 
The node represents the events and each leaf the possible solutions. The null-leaf is the solution without the solution, i.e. there is no solution for the given conditions.

Attribute: Mechanical load. The mechanical load implies the effects of external forces and momenta. It is necessary to know how the pipe will behave under the specific loads. In that way, the pipes can be properly designed according to the customer demands. The examples of mechanical loads are: impacts, bending, cutting stress, pressure and vibration.

\begin{tabular}{|c|c|c|}
\hline Attributes & \multicolumn{2}{|c|}{ Attribute values } \\
\hline Mechanical load & $\begin{array}{ll}\text { - } & \text { heavy } \\
\text { - } & \text { light }\end{array}$ & \\
\hline Material & $\begin{array}{ll}\text { - } & \text { thermo } \\
\text { - } & \text { PVC } \\
\text { - } & \text { polyetl } \\
\end{array}$ & \\
\hline Colour & $\begin{array}{ll}- & \text { orange } \\
\text { - } & \text { grey } \\
\text { - } & \text { yellow } \\
\end{array}$ & $\begin{array}{ll}\text { - } & \text { black } \\
\text { - } & \text { blue } \\
\text { - } & \text { green } \\
\end{array}$ \\
\hline Flame resistance & $\begin{array}{ll}\text { - } & \text { self-ex } \\
\text { - } & \text { non-se }\end{array}$ & $\begin{array}{l}\text { ng } \\
\text { lishing }\end{array}$ \\
\hline Length (m) & $\begin{array}{ll}- & 3 \\
- & 25 \\
\end{array}$ & $\begin{array}{ll}-30 \\
\text { - } & 50 \\
\end{array}$ \\
\hline Packaging (m) & $\begin{array}{ll}\cdot & 45 \\
\text { - } & 50 \\
\text { - } & 90 \\
\text { - } & 100\end{array}$ & $\begin{array}{ll}- & 102 \\
- & 250 \\
- & 500\end{array}$ \\
\hline Temperature range $\left({ }^{\circ} \mathrm{C}\right)$ & $\begin{array}{ll}- & \text { from }- \\
- & \text { from }- \\
- & \text { from }- \\
- & \text { from } \\
- & \text { from } \\
\end{array}$ & $\begin{array}{l}90^{\circ} \mathrm{C} \\
60^{\circ} \mathrm{C} \\
1160^{\circ} \mathrm{C} \\
1160^{\circ} \mathrm{C} \\
1190^{\circ} \mathrm{C} \\
\end{array}$ \\
\hline Outer diameter (mm) & $\begin{array}{ll}\text { - } & 11,5 \\
\text { - } & 12,6 \\
\text { - } & 14,7 \\
\text { - } & 16 \\
\text { - } & 16,1 \\
\text { - } & 16,4 \\
\text { - } & 18,8 \\
\text { - } & 18,9 \\
\text { - } & 20 \\
\text { - } & 20,7 \\
\text { - } & 24,7 \\
\text { - } & 25 \\
\text { - } & 26,1 \\
\text { - } & 27,7 \\
\text { - } & 30,6 \\
\text { - } & 32 \\
\end{array}$ & $\begin{array}{ll} & 33,2 \\
\text { - } & 33,5 \\
\text { - } & 38 \\
\text { - } & 40 \\
\text { - } & 41 \\
\text { - } & 46.4 \\
\text { - } & 50 \\
\text { - } & 63 \\
\text { - } & 75 \\
\text { - } & 90 \\
\text { - } & 110 \\
\text { - } & 125 \\
\text { - } & 140 \\
\text { - } & 160 \\
\text { - } & 200\end{array}$ \\
\hline
\end{tabular}

Attribute: Material.

- Thermoplastic HDP - a polymer material with garnet and linear macromolecules. It is fusible, resistant to shock, pressure and external influences such as water, oil, building materials and corrosive substances [11].

- Polyethylene - Thermoplastic material which is the result of the polymerisation of ethylene and belongs to the group of polymers. It is one of the most used plastic materials. Polyethylene of high density can be applied for the pipes with the good strength at low temperature $[13,14]$.

- Polyvinyl chloride - PVC - a material that is resistant to acids, alkalis, benzene, oils and organic solvents (except ketones and aromatics). The solid PVC is ductile and self-extinguishing, resistant to external influences, shape persistent, has good electrical features, resistant to heating till $80{ }^{\circ} \mathrm{C}$, does not absorb the water, gas tight [14].

Attribute: Colour. The colour selection is done according to the RAL standard and halftone code. The chosen colours [15] are: orange, yellow, grey, black, blue and green.

Attribute: Flame resistance. According to flame resistance, the pipes can be self-extinguishing and nonself-extinguishing. The self-extinguishing pipes are produced from PVC and they are resistant to flame, while the thermoplastic and polyethylene pipes are not flame resistant $[13,14]$.

Attribute: Packaging and length. These attributes refer to the pipe length and packaging. The hard and light flounce flexible pipes can be sold in reels folded by the plastic cling film with heavy elasticity and very easy for transportation and usage. The solid pipes are delivered as the nest of tubes $[13,14]$.

Attribute: Temperature range. This attribute represents the temperature range the pipes can be exposed to, and where deformability and resistance to external influences cannot occur.

Attribute: Outer diameter. The outer diameter presents the external diameter of pipes and its dimension.

The following types of pipes have been produced [8, 9]: wiring finned tubes (TC), electro-ribbed tubes for flush applications (ERC), finned tubes with double walls (Novotub), spiral corrugated pipes (as FLEX), electrostraight pipe-wall laying PNT, onions flat PNT tubes, clamps for flat PNT tubes, connectors for straight pipes PNT, junction boxes, channels, drinking water pipes, gas pipes, protective tubes, micro tubes, etc.

\section{Example of selection of installation pipes by the application of expert system}

The expert system enables the end-user to choose the best solution according to the requirements. It provides the monitoring of system behaviour with the identification of deviations that can endanger the functioning of system and enables making of reliable and safe decisions with the aim to take actions in the system according to the up-todate data and events. The system is based on knowledge that is presented by a decision tree, rules and events. The development of knowledge based system is a very complex process with many problems because the expertise, know-how, procedures, policies and other business knowledge are often inaccessible. The decisions are made according to the attributes which are defined by the experts, and which the end-users choose through the dialogues, calculations or reading of the existing data. The case table contains a list of examples or rules that show which decision will be taken into consideration according to a combination of attributes.

The attributes in the decision tree or case table can be presented by some other decision tree or case table. The constraints enable the creation of such rules which will provide that only the eligible combination from the set can be chosen according to the end-user requirements. 
The expert system is structured as a project (Fig. 1). Each module consists of objects - attributes, procedures, user interface and reports, variables and optimisation tools. First, the attributes have to be defined, as well as their values.



Figure 1 Project review for selected problem

Fig. 2 shows a case table for the selection of installation pipes. There are 860 rows, and that is only a part of the possible combinations of mentioned problem.

\begin{tabular}{|c|c|c|c|c|c|}
\hline 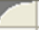 & Colour & Mechanical load & Flame resistance & Length & Packaging ^ \\
\hline 820 & black & light & self-extinguishing & 25 & 100 \\
\hline 821 & black & light & self-extinguishing & 25 & 250 \\
\hline 822 & black & light & self-extinguishing & 25 & 500 \\
\hline 823 & black & light & self-extinguishing & 30 & 90 \\
\hline 824 & black & light & self-extinguishing & 50 & 100 \\
\hline 825 & black & light & self-extinguishing & 50 & 250 \\
\hline 826 & black & light & self-extinguishing & 50 & 500 \\
\hline 827 & orange & light & self-extinguishing & 25 & 100 \\
\hline 828 & orange & light & self-extinguishing & 25 & 250 \\
\hline 829 & orange & light & self-extinguishing & 25 & 500 \\
\hline 830 & orange & light & self-extinguishing & 30 & 90 \\
\hline 831 & orange & light & self-extinguishing & 50 & 100 \\
\hline 832 & orange & light & self-extinguishing & 50 & 250 \\
\hline 833 & orange & light & self-extinguishing & 50 & 500 \\
\hline 834 & blue & light & self-extinguishing & 25 & 100 \\
\hline 835 & blue & light & self-extinguishing & 25 & 250 \\
\hline 836 & blue & light & self-extinguishing & 25 & 500 \\
\hline 837 & blue & light & self-extinguishing & 30 & 90 \\
\hline 838 & blue & light & self-extinguishing & 50 & 100 \\
\hline 839 & blue & light & self-extinguishing & 50 & 250 \\
\hline 840 & blue & light & self-extinguishing & 50 & 500 \\
\hline 841 & green & light & self-extinguishing & 25 & 100 \\
\hline$<$ & & IIIII & & & $\geq$ \\
\hline
\end{tabular}

Figure 2 Case table for selected problem

There are also 860 rows, which describe the instances for the different attributes combination (Fig. 3).

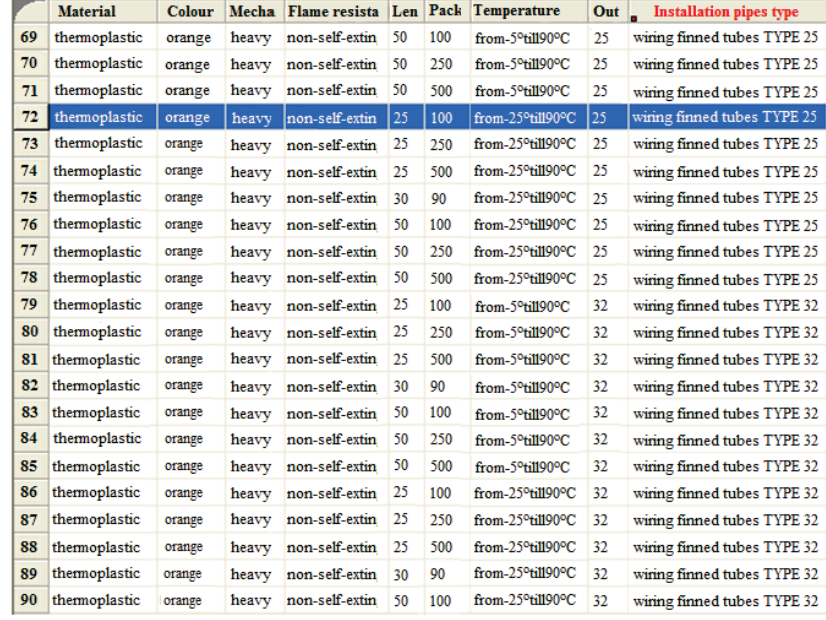

Figure 3 Instance table for selected problem

How huge the problem is, can be represented by the decision tree that can be shown in a full scale only part by part. The short version of decision tree is shown in Fig. 4.

Through the number of dialogue boxes (some of them are shown in Fig. 5 and Fig. 6), the values will be specified and according to these values, the type of installation pipes will be set. The changes in values of each attribute have an influence on the type of installation pipes.

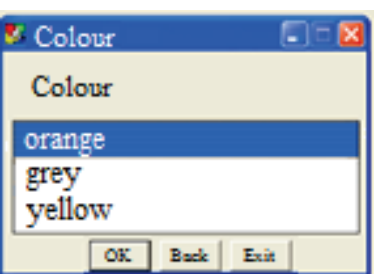

Figure 5 Selection of value for attribute Colour

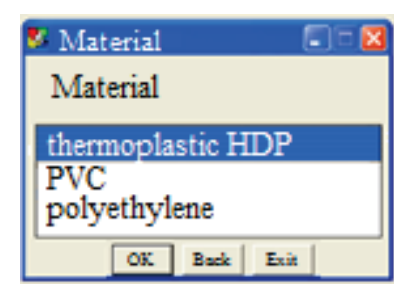

Figure 6 Selection of value for attribute Material
The given output values are shown in Fig. 7.

3. Ropsen
Selected type of installation pipe for selected attributes
wiring finned tubes TYPE 25
$\alpha$ a

Figure 7 Preview of given installation pipe type for selected example

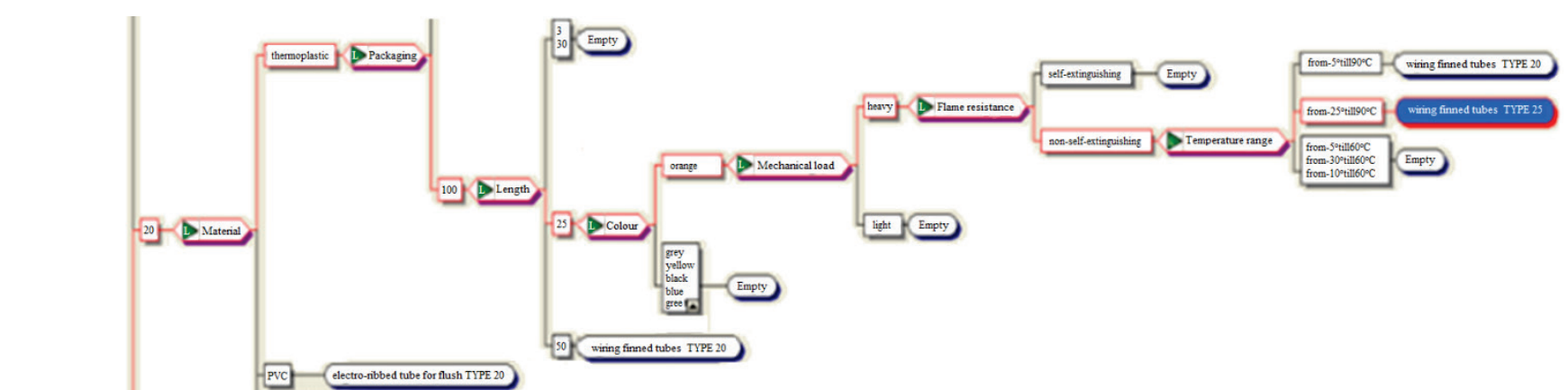

Figure 4 Decision tree 


\section{Conclusion}

The production enterprises want to minimize the overall production costs, to keep the quality of products and to increase their competitiveness. Through the product quality, the enterprises strive to attract the new customers and to increase the efficiency and productivity. Therefore, the organisation, quality of experts and knowledge are becoming more and more important to any enterprise.

The aim of this paper is to predict the input values of attributes which will allow the required output type of installation pipe through the application of expert system. The input values are given through the following attributes: mechanical load, material, colour, flame resistance, length, packaging, temperature range and outer diameter.

The results of the implemented model can be divided in a practical and theoretical way. The theoretical result is achieved through the making of model for the selection of installation pipes. The practical results are realised through the decision making as soon as possible and the possible implementation of model in the Management Information System as a support to the decision making.

The application of expert systems decreases the costs, it can be used in hazardous areas, and they cannot get tired, like the experts who are solving the problem. They can give a second opinion, an explicit and detailed interpretation of conclusions. They have the intelligent knowledge base and the possibility to adopt new knowledge. Even these expert systems have some disadvantages: they use only the stored data to make decisions. Therefore, it is necessary to change the information according to the real situation in the environment.

Further improvement steps are: to incorporate other attributes that could have some influence on the process of selection of installation pipes (which are not included in this paper) and to increase the knowledge base with the new data.

The application of expert systems makes the work easier, and further prosperity and development of enterprises can be achieved in that way.

\section{References}

[1] Majdandžić, N. et al. Upravljanje proizvodnjom. SlavonskiBrod: Strojarskifakultet u Slavonskom Brodu, 2001, pp. 357.

[2] Lujić, R. et al. Applications of Expert System to the Cutting Parameters Problem. // $1^{\text {st }}$ international scientific conference Manufacturing engineering \& management / Hloch, Sergej et al. (ed.). Prešov: Faculty of Manufacturing Technologies Technical University of Košice with a seat in Prešov, 2010, pp. 106-110.

[3] Davis, P. et al. A selection framework for infrastructure condition monitoring technologies in water and wastewater networks. // Expert Systems with Application. 40, 6(2013), pp. 1947-1958.

[4] Scholten, L. et al. Combining expert knowledge and local data for improved service life modeling of water supply networks. // Journal of Environmental Modelling \& Software. 42, (2013), pp. 1-16.

[5] Maine, E.; Probert, D.; Ashby, M. Investing in new materials: a tool for technology managers. // Technovation. 25, 1(2005), pp. 15-23.

[6] Rao, R. V.; Davim, J. P. A decision-making framework model for material selection using a combined multiple attribute decision-making method. // International Journal of Advanced Manufacturing Technology. 35, 7-8(2008), pp. 751-760.

[7] Jahan, A. et al. A framework for weighting of criteria in ranking stage of material selection process. // International Journal of Advanced Manufacturing Technology. 58, 14(2012), pp. 411-420

[8] Novaković, B.; Majetić, D.; Široki, M. Umjetne neuronske mreže. Zagreb: Fakultet strojarstva i brodogradnje, 1998, pp. 240.

[9] Majdandžić, N.; Damjanović-Živić, D. Primjena ekspertnih sustava. Slavonski Brod: Strojarski fakultet u Slavonskom Brodu, 1993, pp. 112.

[10] Mišljenčević, D.; Maršić, I. Umjetna inteligencija. Zagreb:Školska knjiga Zagreb, 1991, pp. 249.

[11] TELUR d.o.o.: Internal document, Zagreb, 2008, pp. 38.

[12] TELUR d.o.o.: Technical catalogue, Zagreb, http://www.telur.hr/. (10.6.2014)

[13] Pet reciklaža: Šta je PE (polietilen) od koga se pravi plastična ambalaža, Merošina, Srbija, 2011.

http://www.petreciklaza.com/Sta-je-PE-polietilen-od-koga-sepravi-plasticna-ambalaza-47.html. (15.6.2014)

[14] Filetin, T.; Kovačiček, F.; Indof, J. Svojstva i primjena materijala. Zagreb: Fakultet strojarstva i brodogradnje, 2007, pp. 372

[15] E-paint, United Kingdom: RAL Colour Chart, 2014. http://www.e-paint.co.uk/RAL_Colourchart.asp. (17.6.2014)

\section{Authors' addresses}

Roberto Lujić, full professor

Mechanical Engineering Faculty in Slavonski Brod Trg I. B. Mažuranić 2, 35000 Slavonski Brod, Croatia E-mail: roberto.lujic@sfsb.hr

Ivan Samardžić, full professor

Mechanical Engineering Faculty in Slavonski Brod Trg I. B. Mažuranić 2, 35000 Slavonski Brod, Croatia E-mail: ivan.samardzic@sfsb.hr

Vjekoslav Galzina, senior assistant Mechanical Engineering Faculty in Slavonski Brod Trg I. B. Mažuranić 2, 35000 Slavonski Brod, Croatia E-mail: vjekoslav.galzina@sfsb.hr 